\title{
Agronomic characterization of citrandarin fruits and seeds
}

\author{
Evandro Henrique Schinor ${ }^{*} \circledast$, Marcelo Arakaki'@, Mariângela Cristofani-Yaly²®
}

'Federal University of São Carlos, Araras, Brazil

${ }^{2}$ Sylvio Moreira Citrus Research Center, Cordeirópolis, Brazil

*Corresponding author, e-mail: ehschinor@ufscar.br

\begin{abstract}
In citrus cultivation, rootstocks are of fundamental importance and affect several characteristics of the variety used as canopy. Despite the great diversity within Citrus and related genera, the production of rootstocks in Brazil is restricted to a small number of varieties, making the citrus culture vulnerable to the appearance of phytosanitary problems. The aim of this study was to agronomically characterize fruits and seeds of seven citrandarins [Citrus sunki (Hayata) hort. ex Tanaka x Poncirus trifoliata cv. Rubidoux (L.) Raf.], obtained by controlled crossing. The orchard was installed in randomized blocks, with three replicates, in the municipality of Cordeirópolis, SP, where 20 fruits were collected in each replicate, obtained from free pollination of seven citrandarins, Swingle citrumelo and Rangpur lime. The following variables were evaluated: fruit mass, height, diameter, total number of seeds and percentage of viable seeds per fruit; number of embryos per seed, mass of one thousand seeds, number of seeds in $1.0 \mathrm{~kg}$, final emergence rate, number of seedlings per seed, polyembryony rate, emergence speed index and seedling height at 60 days after sowing. For fruit size, the highest values were obtained for Swingle citrumelo. For number of embryos per seed, seedlings obtained through seed and polyembryony, citrandarin TSxPT 245 showed the highest values. Although citrandarin fruits had smaller size than fruits from commercial Rangpur lime and Swingle citrumelo rootstocks, characteristics related to seeds such as viability, polyembryony and emergence rate, were similar or superior, and can be considered potential new rootstocks for the production of citrus plants.
\end{abstract}

Keywords: rootstock, Citrus sunki, Poncirus trifoliata, polyembryony, hybrids

\section{Introduction}

Citriculture is one of the main sectors of the Brazilian economy today, with Brazil leading the world orange production and, in 2018, produced around 16.7 million tons in harvested area of 589 thousand hectares (FAO, 2020). São Paulo is the main citrus producing state in Brazil with 12.9 million tons, corresponding to $77.1 \%$ of the national orange production (IBGE, 2020).

Despite the economic importance of citrus for Brazil and the great diversity and variety of citrus species, the production of rootstocks is restricted to a small number of varieties (Guerra et al., 2012). According to Conceição et al. (2019), citing unpublished data from the Agricultural Defense Coordination, Rangpur lime (Citrus limonia Osbeck) and Swingle citrumelo [C. paradisi Macfad. cv. Duncan x Poncirus trifoliata (L.) Raf.] represented, respectively, $34.3 \%$ and $45 \%$ of rootstocks used for the production of citrus seedlings in São Paulo in 2017.
During previous decades, there was an almost exclusive use of Rangpur lime as rootstock for citrus and this monocultural scenario made citrus cultivation vulnerable to the appearance of phytosanitary problems or intensified existing ones, and producers had no guarantees of their continuity due to increased production costs, tree eradication due to diseases such as huanglongbing (Candidatus Liberibacter spp) and citrus sudden death (CSD) and, consequently, loss of area to other crops (Rodrigues et al., 2015; FUNDECITRUS, 2017). In more recent years, the replacement of Rangpur lime by Swingle citrumelo has allowed citrus sudden death to be overcome; however, Swingle citrumelo has low drought tolerance and is incompatible with Pera sweet orange. Therefore, the diversification in the use of rootstocks is a topic of great importance for national citrus culture and should be deeply studied.

In citrus cultivation, rootstocks are of great 
importance and can affect several characteristics of the canopy variety, highlighting plant vigor and size, nutritional content of leaves, production and precocity, in addition to influencing tolerance or resistance to pests, diseases and drought. In fruits, they affect size, acidity, total soluble solids content and juice percentage (Schäfer et al., 2001; Pompeu Junior, 2005; Schinor et al., 2013).

Citrandarins are hybrids from the cross between mandarins and $P$. trifoliata, which it was intended to obtain rootstocks with good characteristics presented by mandarins such as tolerance to decline, to citrus exocortis viroid, to CSD and to calcareous soils, to those of trifoliata, such as immunity to the citrus tristeza virus (CTV), resistance to citrus nematodes, to Phytophthora gummosis and CSD, in addition to obtaining a dwarfing rootstock, capable of inducing the formation of compact and productive plants (Blumer \& Pompeu Junior, 2005; Schinor et al., 2013; Pompeu Junior \& Blumer, 2014).

For Santos et al. (2015), commercial rootstocks must have high seed production and high polyembryony rate. Some agronomic characterization studies of new citrus hybrid rootstocks, mainly citrandarins, with the aim of evaluating and characterizing fruits, seeds and initial seedling development, have been developed in recent years (Schinor et al., 2015; Rodrigues et al., 2015; Conceição et al., 2019; Sombra et al., 2019). However, the development and study of new varieties is necessary to increase the diversity of rootstocks, providing greater durability to citrus orchards. Thus, the aim of this study was to carry out the agronomic characterization of fruits and seeds of seven citrandarin varieties in comparison to Swingle citrumelo and Rangpur lime.

\section{Material and Methods}

This work was carried out at the Center for Agricultural Sciences (CCA) - Federal University of São Carlos, municipality of Araras, SP, located at $22^{\circ} 12$ 'S and $47^{\circ} 13^{\prime} \mathrm{W}$ and $620 \mathrm{~m}$ a.s.I. According to the Köeppen classification, the region's climate is of Cwa type, with average annual rainfall of $1,384 \mathrm{~mm}$ and average annual temperature of $21.6^{\circ} \mathrm{C}$.

In the month of June 2016, ripe fruits were collected from seven citrandarin varieties [C. sunki (Hayata) hort. ex Tanaka x P. trifoliata cV. Rubidoux (L.) Raf. - TS x PT], Rangpur lime IAC863 and Swingle citrumelo, all grafted on Rangpur lime in an experimental orchard at the "Sylvio Moreira" Citriculture Center of the Agronomic Institute (CCSM / IAC), located in Cordeirópolis, SP (22³2'S and $47^{\circ} 27^{\prime} \mathrm{W}$, and $639 \mathrm{~m}$ a.s.l.). Twenty fruits, obtained from free pollination under the same environmental conditions, were collected from each of the three replicates arranged in randomized blocks. The varieties studied, identified with their CCSM/IAC citrus germplasm bank code were citrandarins TSXPT 123 (3123), TSXPT 222 (3222), TSxPT 239 (3239), TSxPT 245 (3245), TSxPT 254 (3254), TSXPT 281 (3281) and TSxPT 282 (3282), Rangpur lime (1219) and Swingle citrumelo (1727). Citrandarins were developed by hybridization controlled by the CCSM/IAC citrus breeding program (Cristofani-Yaly et al., 2005).

Fruit height and diameter was determined using graduated ruler and mass was obtained on analytical scale. Then, fruits were superficially cut in the crosssection direction and submitted to manual twisting for the extraction of seeds, guaranteeing their integrity. With the aid of spatula, seeds were extracted and counted with the aid of analog counter, being separated into two groups: viable (full and well-shaped seeds) and unviable (aborted and / or deformed seeds), considering the total number of seeds per fruit, the sum of viable and unviable seeds. Subsequently, the percentage of viable seeds per fruit was calculated. Viable seeds were placed in sieve and washed in running water to remove mucilage and dried at room temperature, in the shade, for 48 hours. After drying, viable seeds were weighed on a precision scale and their weight was estimated for an amount of 1000 units and the number of seeds in one kilogram.

To count the number of embryos with visible cotyledons, 20 viable seeds per replicate of each variety had the tegument (tegma + coat) removed with the aid of scalpel, totaling 60 seeds per treatment. The rest of seeds of each variety were placed in paper bags, duly identified, and stored in refrigerator at $8^{\circ} \mathrm{C}$.

In August 2016, the seed coat was manually removed from seeds of each rootstock variety and were sown in 32-cell plastic trays $\left(190 \mathrm{~mL} \mathrm{cell}{ }^{-1}\right)$, containing Holambra® commercial substrate (crushed pine bark + vermiculite). Only one seed per cell was sown. The experiment was conducted in greenhouse at CCA for 60 days. The experimental design was completely randomized with four replicates (eight seeds for each repetition), totaling 32 seeds per treatment.

Seedling development was weekly evaluated until 60 days after sowing (DAS). Final emergence rate (FER), number of seedlings per seed and polyembryony rate were verified. The emergence speed index (ESI) was calculated using the following equation: $E S I=(G 1 / N 1)$ $+(\mathrm{G} 2 / \mathrm{N} 2)+(\mathrm{G} 3 / \mathrm{N} 3)+\ldots+(\mathrm{Gn} / \mathrm{Nn})$, where: $\mathrm{ESI}=$ emergence speed index; G1, G2, G3, ..., Gn = number of seedlings computed in the first, second, third and last count and N1, N2, N3,..., Nn = number of days from sowing to the first, second, third and last count (Rodrigues 
et al., 2015). Counts were performed at 7, 14, 21, 28, 35, 42, 49, 56 and 60 DAS. At 60 DAS, seedling height was measured with the aid of ruler graduated in centimeters.

From results obtained, analysis of variance (ANOVA) was performed and means were compared by the Scott-Knott test at $5 \%$ probability using the SASMAgri software (Canteri et al., 2001). For statistical analysis, fruit mass averages were transformed into $(x+1)^{0.5}$ and polyembryony into arcsine $(x / 100)^{0.5}$.

\section{Results and Discussion}

For variables fruit size (mass, height and diameter), the variety that presented the highest average values was Swingle citrumelo, differing from Rangpur lime (intermediate values) and also from the seven citrandarins evaluated that presented the lowest values (Table 1).

Among citrandarins, TSXPT 123 was the only one that presented fruit size averages smaller than the others, with values of $20.0 \mathrm{~g}$ for mass, $30.2 \mathrm{~mm}$ for height and $34.4 \mathrm{~mm}$ for diameter (Table 1), values also lower than those obtained in other studies in which part of the same population of citrandarins was evaluated (Schinor et al., 2015; Conceição et al., 2019). In the work of Schinor et al. (2015), the authors evaluated the attributes of fruits of nineteen citrandarins and found averages ranging from
34.6 to $78.0 \mathrm{~g}$ for mass, 37 to $50 \mathrm{~mm}$ for height and 41 to $56 \mathrm{~mm}$ for diameter. Conceição et al. (2019) evaluated citrandarins 70, 106, 254, 299 and 310 and obtained values ranging from 35.0 to $59.7 \mathrm{~g}$ for mass, 37 to $46 \mathrm{~mm}$ for height and 40 to $48 \mathrm{~mm}$ for fruit diameter. For the other citrandarins evaluated in the present study, values similar to those of Schinor et al. (2015) and Conceição et al. (2019) were obtained. Rodrigues et al. (2015) obtained values of $37.4 \mathrm{~g}, 35.1 \mathrm{~g}$ and $21.4 \mathrm{~g}$ for mass, $36.0 \mathrm{~mm}, 35.5$ $\mathrm{mm}$ and $31.3 \mathrm{~mm}$ for height and $41.3 \mathrm{~mm}, 40.8 \mathrm{~mm}$ and $34.8 \mathrm{~mm}$ for diameter of citrandarins Indio (C. sunki $\times P$. trifoliate cv. English - 256), Riverside (C. sunki x P. trifoliata $C v$. English - 264) and San Diego fruits (C. sunki X P. trifoliate cv. English - 314), respectively, the values of the latter being similar to those of citrandarin TSXPT 123.

Mass (152.4 g), height (71.8 mm) and diameter (67.3 $\mathrm{mm}$ ) values obtained for Swingle citrumelo fruits were higher than those found by Guerra et al. (2012) and Rodrigues et al. (2015), who obtained values of 85.6 and $129.3 \mathrm{~g}$ for mass, 66.0 and $66.9 \mathrm{~mm}$ for height and 65.0 and $62.4 \mathrm{~mm}$ for diameter, respectively. For Rangpur lime, the same authors found values of $65.6 \mathrm{~g}, 49.0 \mathrm{~mm}$ and $48.2 \mathrm{~mm}$ for mass, height and diameter, respectively, lower than those obtained in the present study (Table 1).

Table 1. Mass, height and diameter of fruits of nine citrus rootstocks.

\begin{tabular}{|c|c|c|c|}
\hline Rootstock (BAG CCSM) & Mass (g) & Height (mm) & Diameter (mm) \\
\hline Citrandarin TSxPT 123 (3123) & $20.0 \mathrm{~d}$ & $30.2 \mathrm{~d}$ & $34.4 \mathrm{~d}$ \\
\hline Citrandarin TSxPT 222 (3222) & $42.1 \mathrm{C}$ & $40.4 \mathrm{c}$ & $42.5 \mathrm{c}$ \\
\hline Citrandarin TSxPT 239 (3239) & $42.5 \mathrm{c}$ & $40.8 \mathrm{c}$ & $43.2 \mathrm{c}$ \\
\hline Citrandarin TSxPT 245 (3245) & $35.8 \mathrm{c}$ & $37.9 \mathrm{c}$ & $41.8 \mathrm{C}$ \\
\hline Citrandarin TSxPT 254 (3254) & $41.4 \mathrm{C}$ & $39.8 \mathrm{c}$ & $42.8 \mathrm{C}$ \\
\hline Citrandarin TSxPT 281 (3281) & $50.3 \mathrm{c}$ & $44.7 \mathrm{c}$ & $45.8 \mathrm{C}$ \\
\hline Citrandarin TSxPT 282 (3282) & $38.0 \mathrm{c}$ & $39.2 \mathrm{C}$ & $41.6 \mathrm{C}$ \\
\hline Swingle Citrumelo (1727) & $152.4 \mathrm{a}$ & $71.8 \mathrm{a}$ & $67.3 \mathrm{a}$ \\
\hline Rangpur lime(1219) & $93.2 \mathrm{~b}$ & $54.8 \mathrm{~b}$ & $56.9 \mathrm{~b}$ \\
\hline C.V. (\%) & 8.73 & 6.48 & 5.88 \\
\hline
\end{tabular}

The differences observed for fruit size between varieties and hybrids of the same population (mass, height and diameter) evaluated in this work may be related to the specific characteristics intrinsic to each variety (Conceição et al., 2019) and also to factors associated to management, environmental factors and the possible diversity of selection of rootstock species (Guerra et al., 2012).

Swingle citrumelo showed higher total number of seeds per fruit (32.3), differing from the other rootstocks evaluated (Table 2). However, this characteristic of Swingle citrumelo is linked to the high rate of unviable seeds, which in the present experiment was $49.8 \%$. Guerra et al. (2012) observed the same behavior for Swingle

citrumelo, where, despite having found 38.8 seeds per fruit, the rate of unviable seeds was $40.2 \%$. Citrandarins did not differ from Rangpur lime for total number of seeds per fruit; however, citrandarins TSXPT 123 and TSXPT 239 presented smaller numbers of viable seeds compared to Rangpur lime and other citrandarins. Of the seven citrandarins, five of them showed good potential for producing viable seeds, as well as traditional Rangpur lime (Table 2). Citrandarins TSXPT 222, TSxPT 245, TSxPT 254, TSXPT 281 and TSXPT 282 showed seed viability similar to those of citrandarins Indio (85\%) and Riverside (91.5\%), analyzed in the work of Rodrigues et al. (2015).

Regarding the number of embryos per seed, citrandarin TSXPT 245 presented the highest number (3.0), 
differing from citrandarins TSXPT 222 and TSXPT 123, which presented intermediate values of 2.7 and 2.5 , respectively, and the other citrandarins, Rangpur lime and Swingle citrumelo, which presented lower values, ranging from 2.0 to 2.2 (Table 2). Schinor et al. (2015) evaluated the attributes of fruits and vegetative growth in a nursery of part of the same population of citrandarins and found values between 1.6 and 4.5 embryos per seed. Duarte et al. (2013) obtained values of 4.9, 4.8 and 6.0 embryos per seed for citrandarins Indio, Riverside and San Diego, respectively. According to Schinor et al. (2015), the use of rootstocks that produce polyembryonic seeds is of fundamental importance for greater uniformity of plants in the nursery and the greater the number of embryos per seed, the greater the chances of germination of seedlings of nucellar origin similar to the mother plant. In the present study, citrandarins showed the characteristic of producing seeds with more than one embryo, which can be considered potential rootstocks for citrus culture.

Table 2. Total number of seeds (TNS) and percentage of viable seeds (PVS) per fruit, number of embryos per seed (NES), mass of one thousand seeds (MTS) and number of seeds in $1 \mathrm{~kg}$ (NSK), of nine citrus rootstocks.

\begin{tabular}{cccccc}
\hline Rootstock (BAG CCSM) & TNS & PVS & NES & MTS $(g)$ & NSK \\
\hline Citrandarin TSXPT 123 (3123) & $17.5 \mathrm{~b}$ & $72.8 \mathrm{~b}$ & $2.47 \mathrm{~b}$ & $73.8 \mathrm{c}$ & $13.550 \mathrm{~b}$ \\
Citrandarin TSXPT 222 (3222) & $17.2 \mathrm{~b}$ & $85.7 \mathrm{a}$ & $2.67 \mathrm{~b}$ & $113.4 \mathrm{~b}$ & $8.816 \mathrm{~d}$ \\
Citrandarin TSXPT 239 (3239) & $21.0 \mathrm{~b}$ & $74.0 \mathrm{~b}$ & $2.03 \mathrm{c}$ & $83.4 \mathrm{c}$ & $11.986 \mathrm{c}$ \\
Citrandarin TSXPT 245 (3245) & $17.9 \mathrm{~b}$ & $84.9 \mathrm{a}$ & $2.98 \mathrm{a}$ & $147.2 \mathrm{a}$ & $6.793 \mathrm{e}$ \\
Citrandarin TSXPT 254 (3254) & $16.7 \mathrm{~b}$ & $87.7 \mathrm{a}$ & $2.12 \mathrm{c}$ & $108.0 \mathrm{~b}$ & $9.256 \mathrm{~d}$ \\
Citrandarin TSXPT 281 (3281) & $13.7 \mathrm{~b}$ & $84.5 \mathrm{a}$ & $2.08 \mathrm{c}$ & $124.4 \mathrm{~b}$ & $8.041 \mathrm{~d}$ \\
Citrandarin TSXPT 282 (3282) & $15.7 \mathrm{~b}$ & $86.5 \mathrm{a}$ & $2.20 \mathrm{c}$ & $126.9 \mathrm{~b}$ & $7.880 \mathrm{~d}$ \\
Swingle Citrumelo (1727) & $32.3 \mathrm{a}$ & $50.2 \mathrm{c}$ & $2.02 \mathrm{c}$ & $163.7 \mathrm{a}$ & $6.110 \mathrm{e}$ \\
Rangpur lime (1219) & $13.9 \mathrm{~b}$ & $86.1 \mathrm{a}$ & $2.00 \mathrm{c}$ & $49.9 \mathrm{c}$ & $20.053 \mathrm{a}$ \\
\hline C.V. (\%) & 15.99 & 8.29 & 6.70 & 16.41 & 10.79 \\
\hline
\end{tabular}

Means followed by the same letter in column do not differ by the Scott-Knott test at $5 \%$ probability.

For mass of 1000 seeds, the highest averages were obtained with Swingle citrumelo (163.7 g) and citrandarin TSXPT 245 (147.2 g) and, consequently, smaller numbers of seeds in $1 \mathrm{~kg}$ were found for these rootstocks. Rangpur lime together with citrandarins TSXPT 123 and TSXPT 239 had the lowest average for mass of 1000 seed, whereas Rangpur lime had the highest number of seeds in $1 \mathrm{~kg}$, differing from the other rootstocks evaluated (Table 2). The value observed in this work of $49.9 \mathrm{~g}$ of 1000 Rangpur lime seeds was lower than $76.9 \mathrm{~g}$ obtained in the study by Struiving et al. (2013). These authors reported values of $125.0 \mathrm{~g}$ of 1000 seeds of citrandarin 1710 (C. reticulata - Changsha x P. trifoliata - English Small), a value similar to those obtained for citrandarins TSXPT 222, 254, 281 and 282.

All rootstocks in this study had final emergence rate (FER) above $84 \%$, with no statistical differences between them, with citrandarins TSXPT 123, 254 and 282, together with Rangpur lime and Swingle citrumelo, reaching 100 \% FER (Table 3). Schinor et al. (2015) evaluated the emergence percentage of 19 citrandarins from the same population as those used in this study and found that 18 had values above $60 \%$, and 12 of which with more than $80 \%$ of emergence rate. For citrandarins Indio, Riverside, San Diego and Swingle citrumelo, Rodrigues et al. (2015) obtained 85, 100, 99 and 82\% FER, respectively. Sombra et al. (2019) reported values of 59,64 and $84 \%$ FER, respectively, for citrandarins Indio,
Riverside, San Diego. Conceição et al. (2015) evaluated the quality of Rangpur lime and Swingle citrumelo seeds and observed that the seed emergence rate remained above $80 \%$ until six months of storage. These differences in FER among rootstocks found in several studies may be related to the adequate moisture content in seeds, which guarantees good emergence rates (Rodrigues et al., 2015). According to Conceição et al. (2015), the water content of Rangpur lime and Swingle citrumelo seeds showed significant positive correlation with germination and emergence tests. In Brazil, at least $50 \%$ germination is required for a batch of citrus seeds to be able to be marketed (MAPA, 2013), and all citrandarins evaluated were within minimum standards required by law.

Citrandarin TSXPT 245 showed the highest number of seedlings per seed and the highest polyembryony rate, differing from the other rootstocks, with the lowest values being obtained for citrandarin TSXPT 239 and Rangpur lime (Table 3). According to Guerra et al. (2012), all rootstocks in the present study had lower number of seedlings per seed than the number of embryos obtained by counting using the direct method. For Andrade et al. (2007), this occurs due to the different maturation phases of embryos or to competition for nutrients.

The highest emergence speed rates (ESI) were obtained with citrandarins TSXPT 222, TSXPT 245 and TSXPT 254 (Table 3). Of the seven citrandarins analyzed, only TSXPT 239 was not superior to Rangpur lime (Table 3). In 
the study by Sombra et al. (2019), the ESI values observed for citrandarins Indio (8.00), Riverside (9.75) and San Diego (11.50) were higher than those of citrandarins analyzed in the present study. Higher ESI values indicate that the rootstock presents high vigor and greater initial uniformity in the nursery (Rodrigues et al., 2015).

Table 3. Final emergence rate (FER), number of seedlings per seed (NSS) and polyembryony rate (PR), emergence speed index (ESI) and seedling height at 60 days after sowing (DAS).

\begin{tabular}{cccccc}
\hline Rootstock (BAG CCSM) & FER (\%) & NSS & PR (\%) & ESI & $\begin{array}{c}\text { Height at 60DAS } \\
\text { (cm) }\end{array}$ \\
\hline Citrandarin TSXPT 123 (3123) & $100 \mathrm{a}$ & $2.03 \mathrm{~b}$ & $62.5 \mathrm{~b}$ & $2.62 \mathrm{~b}$ & $4.5 \mathrm{c}$ \\
Citrandarin TSXPT 222 (3222) & $94 \mathrm{a}$ & $2.10 \mathrm{~b}$ & $76.3 \mathrm{~b}$ & $2.99 \mathrm{a}$ & $6.7 \mathrm{a}$ \\
Citrandarin TSXPT 239(3239) & $97 \mathrm{a}$ & $1.38 \mathrm{~d}$ & $31.7 \mathrm{c}$ & $1.75 \mathrm{c}$ & $5.8 \mathrm{~b}$ \\
Citrandarin TSXPT 245 (3245) & $97 \mathrm{a}$ & $2.56 \mathrm{a}$ & $90.6 \mathrm{a}$ & $3.25 \mathrm{a}$ & $5.9 \mathrm{~b}$ \\
Citrandarin TSXPT 254 (3254) & $100 \mathrm{a}$ & $2.03 \mathrm{~b}$ & $65.6 \mathrm{~b}$ & $2.79 \mathrm{a}$ & $5.6 \mathrm{~b}$ \\
Citrandarin TSXPT 281 (3281) & $84 \mathrm{a}$ & $1.77 \mathrm{c}$ & $59.0 \mathrm{~b}$ & $2.23 \mathrm{~b}$ & $6.9 \mathrm{a}$ \\
Citrandarin TSXPT 282 (3282) & $100 \mathrm{a}$ & $1.72 \mathrm{c}$ & $62.5 \mathrm{~b}$ & $2.36 \mathrm{~b}$ & $6.5 \mathrm{a}$ \\
Swingle Citrumelo (1727) & $100 \mathrm{a}$ & $1.84 \mathrm{c}$ & $71.9 \mathrm{~b}$ & $2.44 \mathrm{~b}$ & $7.0 \mathrm{a}$ \\
Rangpur lime (1219) & $100 \mathrm{a}$ & $1.31 \mathrm{~d}$ & $31.3 \mathrm{c}$ & $1.48 \mathrm{c}$ & $5.2 \mathrm{~b}$ \\
\hline C.V. (\%) & 7.55 & 15.43 & 21.84 & 15.17 & 7.59 \\
\hline
\end{tabular}

Swingle citrumelo, together with citrandarins TSxPT 222, TSxPT 281 and TSxPT 282 presented the highest seedling heights at 60 days after sowing (DAS), ranging from 6.5 to $7.0 \mathrm{~cm}$, differing from the other rootstocks, with citrandarin TSXPT 123 presenting the lowest value $(4.5 \mathrm{~cm}$ ) (Table 3). Rodrigues et al. (2015) reported that the height of Swingle citrumelo and citrandarins Indio, Riverside and San Diego seedlings at 33 DAS was 3.9, 4.6, 2.6 and $3.9 \mathrm{~cm}$ respectively. In another study, Sombra et al. (2019), obtained for citrandarins Indio, Riverside and San Diego, height values of 10.0, 9.0 and $11.6 \mathrm{~cm}$ respectively, at $60 \mathrm{DAS}$ and reported that several factors such as photoperiod, temperature, solar radiation, physicochemical composition of the substrate, in addition to the genotypic potential of the variety, may be related to the initial development of rootstocks in greenhouse.

\section{Conclusions}

Citrandarins analyzed in this study presented smaller fruits compared to Rangpur lime and Swingle citrumelo rootstocks; however, characteristics related to seeds, such as viability, polyembryony and emergence rate, were similar or superior, and could be considered potential to be used as new rootstocks for the production of citrus seedlings.

\section{References}

Andrade, R.A., Martins, A.B.G., Lemos, E.G.M., Luz, F.J.F., Silva, M.T.H. 2007. Detecção de polimorfismo em portaenxertos para citros. Revista Brasileira de Fruticultura 29: 345-349.

Blumer, S., Pompeu Junior, J. 2005. Avaliação de citrandarins e outros híbridos de trifoliata como portaenxertos para citros em São Paulo. Revista Brasileira de Fruticultura 27: 264-267.

Canteri, M.G., Althaus, R.A., Virgens Filho, J.S., Giglioti,
E.A., Godoy, C.V. 2001. SASM - Agri: Sistema para análise e separação de médias em experimentos agrícolas pelos métodos Scoft-Knott, Tukey e Duncan. Revista Brasileira de Agrocomputação 1: 18-24.

Conceição, P.M., Azevedo, F.A., Ecker, G.V., Morelli, M., Cristofani-Yaly, M. 2019. Physiological quality of citrandarins, Poncirus trifoliata and Sunki mandarin seeds. Comunicata Scientiae 10: 461-466.

Conceição, P.M., Azevedo, F.A., Hendrikx, W., Martinelli, R., Pacheco, C.A., Carvalho, S.A. 2015. Qualidade de sementes de porta-enxertos de citros do Jardim Clonal do Centro APTA Citros Sylvio Moreira/IAC. Citrus Research \& Technology 36: 9-14.

Cristofani-Yaly, M., Novelli, V.M., Perin, M.S., Oliveira, A.C., Oliveira, R.P., Bastianel, M., Machado, M.A. 2005. Programa de Melhoramento de Citros por hibridação controlada no Centro APTA Citros Sylvio Moreira em 19972005. Laranja 26: 121-134.

Duarte, F.E.V.O., Barros, D.R., Girardi, E.A., Soares Filho, W.S., Passos, O.S. 2013. Poliembrionia e atributos morfológicos de sementes de porta-enxertos de citros. Revista Brasileira de Fruticultura 35: 246-254.

FAO. Food and Agriculture Organization of the United. Crops Production. 2018. Disponível em: <http://www.fao. org/faostat/en/\#data/QC>. Access on 22 Mar. 2020.

FUNDECITRUS. 2017. Inventário de árvores do cinturão citrícola de São Paulo e Triângulo/Sudoeste Mineiro: retrato dos pomares em março de 2017. Fundo de Defesa da Citricultura, Araraquara, Brazil. 95 p.

Guerra, D., Schifino-Wittman, M.T., Schwarz, S.F., Souza, P.V.D., Weiler, R.L. 2012. Caracterização morfológica, determinação do número de embriões e taxa de poliembrionia em três porta-enxertos híbridos de citros. Bragantia 71: 196-201.

IBGE. Instituto Brasileiro de Geografia e Estatística. Sistema IBGE de Recuperação Automática - SIDRA. Previsão de safra. 2018. https://sidra.ibge.gov.br/home/ipca 15/brasil <Access on 22 Mar. 2020>. 
MAPA. Ministério da Agricultura Pecuária e Abastecimento. 2013. www.lex.com.br/legis_24871657_ INSTRUCAO_NORMATIVA_N_48_DE_24_DE_SETEMBRO_ DE_2013.aspx < Access on 15 Apr. 2020>

Pompeu Junior, J., Blumer, S. 2014. Híbridos de trifoliata como porta-enxertos para laranjeira Pêra. Pesquisa Agropecuária Tropical 44: 9-14.

Pompeu Junior, J. 2005. Porta-enxertos. In: Mattos Junior, D., De Negri, J.D., Pio, R.M., Pompeu Junior, J. Citros. Instituto Agronômico e Fundag, Campinas, Brazil. p. 61 104.

Rodrigues, M.J.S., Ledo, C.A.S., Girardi, E.G., Almeida, L.A.H, Soares Filho, W.S. 2015. Caracterização de frutos e propagação de porta-enxertos híbridos de citros em ambiente protegido. Revista Brasileira Fruticultura 37: 457470.

Santos, C.Q.J., Girardi, E.A., Vieira, E.L., Ledo, C.A.S., Soares Filho, W.S. 2015. Tamanho ótimo de amostras de frutos e de sementes para determinação da poliembrionia em citros. Revista Brasileira de Fruticultura 37: 172-178.

Schäfer, G., Bastianel, M., Dornelles, A.L.C. 2001. Portaenxertos utilizados na citricultura. Ciência Rural 31: 723733.

Schinor, E.H., Cristofani-Yaly, M., Bastianel, M., Machado, M.A. 2013. Sunki mandarin vs Poncirus trifoliata hybrids as rootstocks for Pera sweet orange. Journal of Agricultural Science 5: 190-200.

Schinor, E.H., Nascimento, A.L., Barros, V.L.N.P., Bastianel, M., Azevedo, F.A., Cristofani-Yaly, M. 2015. Atributos de frutos e crescimento vegetativo de porta-enxertos de citrandarins em viveiro. Citrus Research \& Technology 36: 27-35.

Sombra, K.E.S., Silva, A.C.C., Loureiro, F.L.C., Andrade, H.M., Bastos, D.C., Uchôa, C.N. 2019. Emergência e desenvolvimento inicial de porta-enxertos de citros no semiárido do Ceará, Brasil. Citrus Research \& Technology 40: e1042.

Struiving, T.B., Machado, D.L.M., Santos, D., Siqueira, D.L., Lucena, C.C., Matarazzo, P.H.M. 2013. Qualidade fisiológica de sementes de citros durante 0 armazenamento em ambiente refrigerado. Ciência Rural 43: 1777-1782.

Conflict of Interest Statement: The authors declare that the research was conducted in the absence of any commercial or financial relationships that could be construed as a potential conflict of interest.

All the contents of this journal, except where otherwise noted, is licensed under a Creative Commons Attribution License attribuition-type BY. 